\section{Som en bikini på Ipanema - liten, men fullt brukbar}

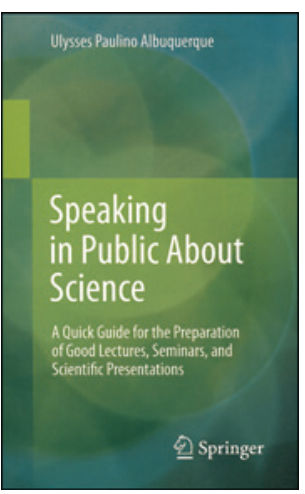

Ulysses Paulino Albuquerque

Speaking in public about science

A quick guide for the preparation of good

lectures, seminars, and scientific presenta-

tions. 68 s. Cham: Springer, 2015.

Pris EUR 20

ISBN 978-3-319-06516-8

Den brasilianske biologiprofessoren Ulysses Paulino Albuquerque vil hjelpe sine lesere med utfordringene som ligger i muntlig akademisk presentasjon. I det han kaller en «booklet», deler han budskapet inn i 11 deler over snaut 60 sider.

Han starter med å adressere behovet for ferdigheter før han gir leseren en selvtest med 30(!) spørsmål og tre svaralternativer - ja, av og til, nei. Resultatet forteller hvordan det står til, fra «You are a good communicator» til «You need to address this matter as soon as possible».

Dernest presenteres hva som er effektiv muntlig kommunikasjon over tre sider, hvor to brasilianske referanser (Krausz og Silva) vektes tungt med budskap som må kunne sies å være i takt med øvrig litteratur på feltet, og god folkeskikk.

Videre går forfatteren mer i detalj på forskjellige typer presentasjoner, litt om forutsetninger og forberedelser og oppbygningen av vitenskapelig diskurs generelt. Boken rundes av med noen regler for bruk av visuelle hjelpemidler, noen nøkler for suksess på podiet og til sist noen øvelser og ressurser på nett.

Boken bærer enkelte steder preg av at den er skrevet av en forfatter som ikke har engelsk som førstespråk. Presentasjon er også kultur. Som norsk lege merker jeg betydelige kulturforskjeller fra det landskapet forfatteren beskriver. Like fullt har mange av forfatterens råd god overførbarhet til norske forhold.

Alle som presenterer muntlig, har et ansvar for å streve etter å bli så god som de kan. Etter å ha sittet på medisinstudiet i seks år og blitt eksponert for kanskje 300 forelesere, mener jeg at mer enn halvparten hadde hatt godt av å titte i denne boken. Ikke fordi den er så god, men fordi man ved å bestemme seg for å ta fatt på akkurat en slik bok faktisk tenker over egne presentasjonsferdigheternoe som kan være første steg i retning av forbedring. Denne flisen av en utgivelse koster 175 kroner. Hvis jeg skulle skaffe meg en slik bok (jeg for øvrig har en håndfull), ville jeg vurdert å tredoble innsatsen og gått for Magne Nylennas Publisere \& Presentere, hvor du over 300 sider også får kvalitativt mer - tilpasset en norsk hverdag.

Albuquerques langt rimeligere og fullt brukbare alternativ er relevant for alle som gir muntlige presentasjoner. Den kan anbefales til doktorgradsstipendiater, især de som er pådyttet undervisningsplikt, men også til erfarne undervisere og forskere som føler at de er et stykke unna virtuost nivå som presentør. Jeg hadde godt av å lese den.

\section{Eirik Hugaas Ofstad}

Lege i spesialisering, Medisinsk avdeling

Nordlandssykehuset Bodø

\section{Optimistisk amerikansk psykiatrihistorie}

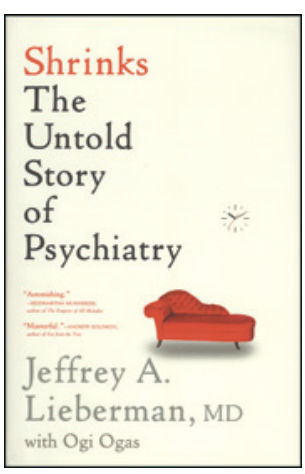

Jeffrey A. Lieberman

\section{Shrinks}

The untold story of psychiatry. 342 s, ill. New York, NY: Little, Brown and Company, 2015. Pris USD 28

ISBN 978-0-316-27886-7

Forfatteren er professor i psykiatri og leder for psykiatriavdelingen ved Colombia-universitetet i New York. Hensikten med denne utgivelsen er å vise at psykiatrien nå er blitt vitenskapelig og kan tilby effektiv behandling for de fleste alvorlige psykiske lidelser, takket være fremskritt innen den biologiske psykiatrien.

De tre hovedkapitlene dreier seg om diagnostikk, behandling og fremtidens psykiatri. Psykiatriens historie er behandlet som en amerikansk historie der forfatteren i mindre grad konsentrerer seg om europeisk psykiatri. Sigmund Freud (1856-1939) utropes til psykiatriens største helt, men samtidig som den mest katastrofale kjeltring. Wilhelm Reich (1897-1957) omtales på flere sider og beskrives som en stor svindler med sitt orgonskap, selv om han spilte en ubetydelig rolle i amerikansk psykiatri etter at han forlot Norge i 1939. Reichs vitenskapelige bidrag før han ble syk er ikke nevnt.

Boken er på ingen måte uinteressant. Den historiske gjennomgangen er ispedd illustrerende anekdoter, og særlig ved utviklingen av de nye psykiatriske medikamentene viser han - som vi for øvrig har hørt før - hvor tilfeldig oppdagelsen av klorpromazin, litium og imipramin var, uten noen klare vitenskapelige hypoteser på forhånd.

Boken gir inntrykk av at de fleste psykiske lidelser lar seg behandle hvis man anvender diagnosemanualer i diagnostikken og medikamenter og i blant kognitiv atferdsterapi i behandlingen. Så enkelt er det vel neppe.

Amerikansk psykiatri har gjennom de siste 150 år gjennomgått ekstreme ideologiske svingninger. Asylpsykiatrien var frem til 1940årene preget av en kraepelinsk psykiatri (etter den tyske psykiateren Emil Kraepelin 1856-1926) med vekt på arv, oppbevaring og somatiske behandlingsmetoder. Så overtok psykoanalysen, ikke minst på grunn av innvandring av jødiske psykiatere fra Europa, som nådde sitt høydepunkt i 1950-, 60- og 70-årene. Etter den tid har den biologiske psykiatrien overtatt. Disse endringene i amerikansk psykiatri gjenspeiles av den statlige forskningspolitikken. Den største føderale forskningsorganisasjonen - National Institute of Mental Health - ble etablert i 1949 med Robert Felix (1904-1990), en praktiserende psykoanalytiker, som sjef. Han avslo stort sett alle bidrag til biologisk forskning. I dag ledes forskningsorganisasjonen av en biolog som gjennomgående avslår alle bidrag til klinisk og sosial forskning.

Den som ønsker å få et inntrykk av amerikansk psykiatri i dag, bør lese boken. Men man bør da vite at bildet som tegnes av psykiatriens utvikling er skjevt, med utelatelser av viktige bidrag fra Europa. Det gjelder både forskning innen psykofarmakologi, epidemiologi, tvilling- og adopsjonsstudier.

Einar Kringlen

Professor, Psykiatrisk institutt, Vinderen

Universitetet i Oslo 